\title{
Fat Necrosis of the Breast Following Folinic Acid Extravasation
}

\author{
Lipoidnekrose der Brust nach Folinsäure-Paravasat
}

Authors

Affiliations
M. Hammon ${ }^{1}$, G. Dilbat ${ }^{2}$, R. Schulz-Wendtland ${ }^{1}$

${ }^{1}$ Radiologisches Institut, Universitätsklinikum Erlangen, Erlangen

2 Radiologie, Radiologiezentrum Roth, Roth

\section{Key words \\ - Fat necrosis \\ - breast \\ - extravasation \\ - mammography \\ o sonography \\ Schlüsselwörter \\ - Lipoidnekrose \\ - Mamma \\ - Paravasat \\ - Mammografie \\ - Ultraschall}

\section{received $\quad 8.12 .2012$ \\ revised $\quad 31.12 .2012$ \\ accepted 4.1.2013}

\section{Bibliography}

DOI http://dx.doi.org/ 10.1055/s-0032-1328191

Geburtsh Frauenheilk 2013; 73: 148-151 @ Georg Thieme Verlag KG Stuttgart · New York . ISSN 0016-5751

\section{Correspondence}

Dr. Matthias Hammon, MD

Universitätsklinikum Erlangen

Radiologisches Institut

91054 Erlangen

matthias.hammon@

uk-erlangen.de

\section{Abstract \\ $\nabla$}

Case Report: We report here on a 58-year-old patient with abnormal findings in the left breast on screening mammography (October 2012). In May 2008 the patient was diagnosed with rectal cancer, subsequently treated by surgical resection followed by radiochemotherapy. In September 2011 the patient was diagnosed with peritoneal cancer. Extravasation of folinic acid occurred during palliative chemotherapy, which was delivered through a surgically implanted port, placed prepectorally on the left side. The patient had not previously undergone breast surgery. The abnormal finding in the left breast was located at the 1-2 o'clock position. The mammogram showed extensive hyperdense nodules with predominantly round, fine granular calcifications. On sonography, the findings presented as a hypoechogenic, inhomogenous, partially diffuse, partly solid, partly cystic mass with individual calcifications and reduced echogenicity in the dorsal aspect. Strong densification of the left breast was found at the corresponding position on palpation. On computed tomography (CT) done during follow-up for rectal cancer, new streaky/pitted densifications were noted in the left breast. Based on the patient's previous history and the results of the breast diagnostics a diagnosis of extensive fat necrosis after folinic acid extravasation was made. No further measures were taken. The patient will continue to be screened using mammography.

Conclusion: A good knowledge of the mammographic and sonographic features of fat necrosis can reduce the number of unnecessary biopsies. Careful consideration of the patient's prior medical history is very important in breast diagnostics and may often be decisive for the correct diagnosis.

\section{Zusammenfassung \\ $\nabla$}

Kasuistik: Wir berichten über eine 58 Jahre alte Patientin, bei der im Mammografie-Screening (Oktober 2012) ein auffälliger Befund in der linken Brust festgestellt wurde. Im Mai 2008 wurde bei der Patientin die Diagnose eines Rektumkarzinoms gestellt, welches chirurgisch und radiochemotherapeutisch behandelt wurde. Im September 2011 wurde die Diagnose einer Peritonealkarzinose gestellt. Die palliative Chemotherapie wurde über einen chirurgisch, links präpektoral angelegten Portkatheter verabreicht. Dabei kam es zu einem Paravasat von Folinsäure. Die Patientin hatte sich bisher keiner Operation der Brust unterzogen. Der auffällige Mammografiebefund in der linken Brust lag bei 1-2 Uhr und zeigte ausgedehnte hyperdense Verdichtungen mit feingranulären, überwiegend runden Verkalkungen. Sonografisch stellte sich der Befund als ein hypoechogener, inhomogener, teils solider, teils liquider, stellenweise unscharf begrenzter Herdbefund mit einzelnen Verkalkungen und einer dorsalen Schallabschwächung dar. Während der Tastuntersuchung konnte man an der korrespondierenden Position eine derbe Verdichtung der linken Brust feststellen. In der im Rahmen der Nachsorge bei Zustand nach Rektumkarzinom durchgeführten Computertomografie (CT) zeigten sich neue, streifig/narbige Verdichtungen in der linken Brust. Aufgrund der Anamnese der Patientin und den Ergebnissen der komplementären Mammadiagnostik konnte die Diagnose einer ausgedehnten Lipoidnekrose nach Folinsäure-Paravasat gestellt werden. Es wurden keine weiteren Maßnahmen ergriffen. Die Patientin verbleibt im Mammografie-Screening.

Fazit: Die Kenntnis der mammografischen und sonografischen Merkmale einer Lipoidnekrose kann die Zahl der unnötigen Biopsien reduzieren. Eine sorgfältig erhobene Anamnese ist von großer Bedeutung in der Mammadiagnostik und oft entscheidend für die richtige Diagnose. 

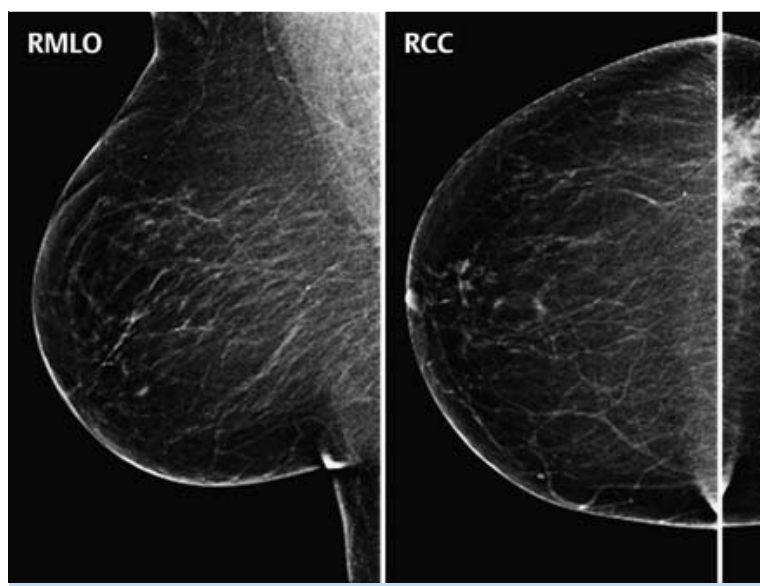

Fig. 1 Bilateral mammography done in 2 projections (MLO, CC) with Cleopatra view of the left breast. Extensive hyperdense nodules and predominantly round, fine granular calcifications are visible in the left breast (1-2
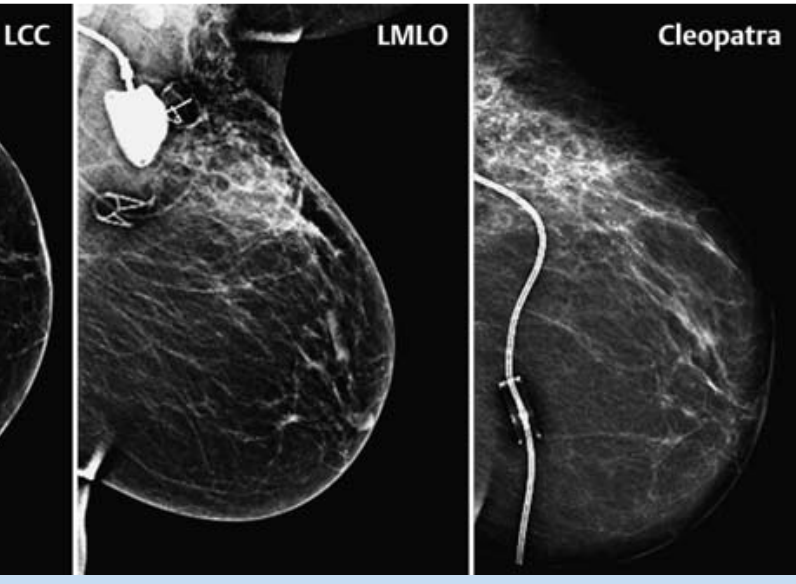

o'clock position) due to fat necrosis after folinic acid extravasation. Prepectoral port chamber access is visible on the left. Normal right breast.

\section{Introduction}

$\nabla$

Chemotherapeutic agents are usually administered via a surgically inserted, permanent, subcutaneous port. The port is implanted prepectorally through a skin incision, and the connected catheter is introduced through the subclavian vein into the superior vena cava using the Seldinger technique. This transcutaneous cannulation allows medication or parenteral nutrition to be infused through a central venous line over longer periods of time. Possible complications include infections, thrombosis, dislocation or extravasation of highly toxic chemotherapeutic agents. Depending on the chemical properties of the chemotherapeutic agent this can result in severe local damage. In the literature, the incidence of extravasation is reported to range between 0.1 and $6.5 \%$. Recommended immediate measures are stopping the infusion, aspiration of the extravasation, local infiltration with the specific antidote and heat treatment or cold compresses [1,2]. In some cases, particularly in the event of an extravasation with a high tissue toxicity, rapid surgical intervention may be necessary. Folinic acid (synonyms: citrovorum factor, leucovorin; formula: $\mathrm{C}_{20} \mathrm{H}_{23} \mathrm{~N}_{7} \mathrm{O}_{7}$ ) is a tetrahydrofolic acid derivative used in the treatment of colorectal cancer for its synergistic effect in combination with the cytostatic drug 5-fluorouracil (5-FU) [3]. Folinic acid and folic acid may also be administered as an antidote in treatments using folic acid antagonists such as methotrexate (MTX) to reduce the risk of an adverse drug reaction (ADR) and, in particular, to reduce hematopoetic toxicity (so-called "leucovorin rescue") [4].

\section{Case Report}

We report here on a 58-year-old patient with abnormal findings in the left breast on screening mammography (October 2012).

In May 2008 the patient was diagnosed with rectal cancer (pT3, pNO [0/25], M0), subsequently treated by surgical resection (deep anterior rectal resection) followed by radiochemotherapy. Chemotherapy (5-fluorouracil) was delivered through a surgically implanted port, placed prepectorally on the left side. In September 2011, after computed tomography (CT) examination the patient was diagnosed with peritoneal cancer with a suspicion of abdominal wall metastasis, subsequently confirmed by histological analysis. The patient was started on palliative chemotherapy (FOLFOX4 regimen + bevacizumab), during which extravasation of folinic acid occurred. As the peritoneal cancer continued to progress, the treatment regimen was switched in March 2012 to irinotecan + bevacizumab. Secondary diagnoses included morbid obesity and Graves' disease treated 10 years previously with radioiodine. The patient had not previously undergone breast surgery.

The abnormal finding in the left breast was located at the 1-2 o'clock position. The mammogram showed extensive $(11 \times 4 \mathrm{~cm})$ hyperdense nodules with predominantly round, fine granular calcifications ( $\boldsymbol{O}$ Fig. $\mathbf{1}$ ). On sonography, the findings presented as a hypoechogenic, inhomogenous, partially diffuse, partly solid, partly cystic mass measuring $3.3 \times 1.0 \times 3.0 \mathrm{~cm}$, with individual calcifications and reduced echogenicity in the dorsal aspect. The findings were located $7 \mathrm{~cm}$ from the nipple and $2 \mathrm{~mm}$ under the skin ( $\bullet$ Fig. 2). Strong densification of the left breast was found at the corresponding position on palpation. The subcutaneous port could be palpated immediately cranial to the densification. On CT done during follow-up for rectal cancer, new streaky/pitted densifications were noted in the left breast ( $\bullet$ Fig. 3 ).

Based on the patient's previous history and the results of the breast diagnostics, a diagnosis of extensive fat necrosis after folinic acid extravasation was made (BI-RADS II). No further measures were taken. The patient will continue to be screened using mammography.

\section{Discussion}

Fat necrosis of the breast is a benign lesion caused by iatrogenic (surgical intervention, biopsy, oral radiotherapy) or non-iatrogenic trauma $[5,6]$. Clinically the course is generally unremarkable, but fat necrosis can manifest itself in the form of soft or compact fixed nodules extending to the overlying skin [7]. The extremely varied morphological characteristics of fat necrosis have been investigated and described in detail in the literature, and a good knowledge of its characteristic images in mammography and sonography is important to differentiate fat necrosis from malignant lesions which may have a similar appearance [8, 


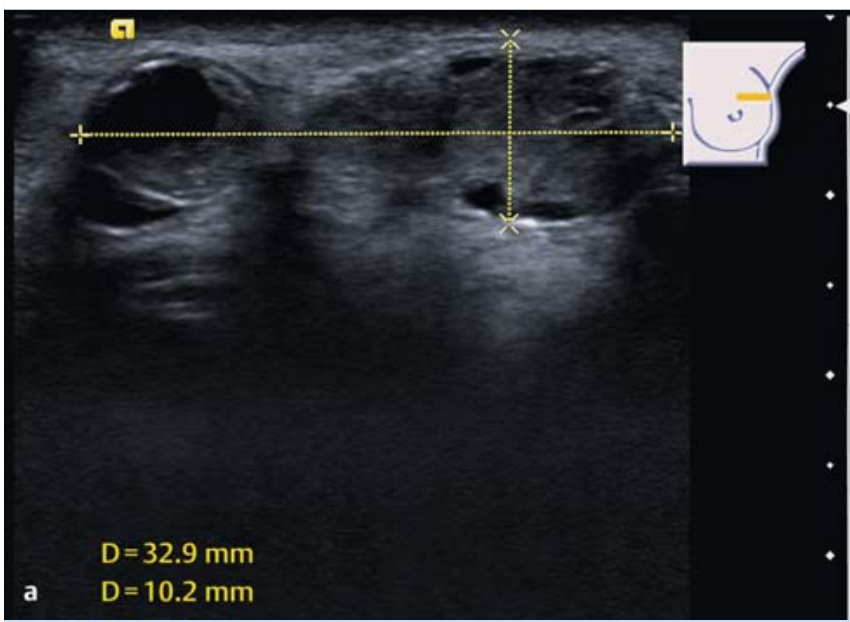

Fig. $2 \mathbf{a}$ and $\mathbf{b}$ Sonographic imaging of the left breast. Mass located $7 \mathrm{~cm}$ from the nipple and $2 \mathrm{~mm}$ under the skin measuring $3.3 \times 1.0 \times 3.0 \mathrm{~cm}$. The image shows a hypoechogenic, inhomogenous, partly solid, partly cystic,

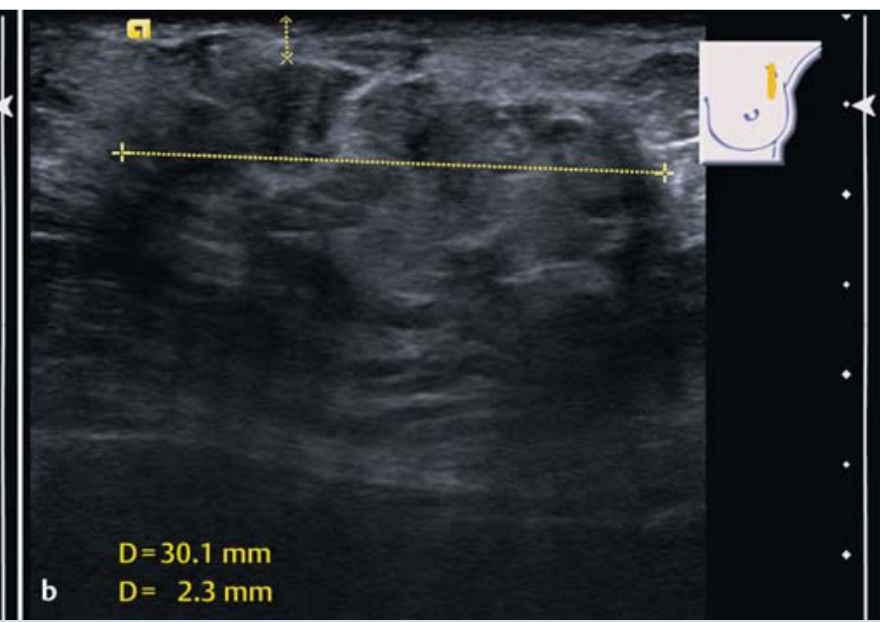

partially diffuse mass with individual calcifications and reduced dorsal echogenicity (a axial plane; b sagittal plane).

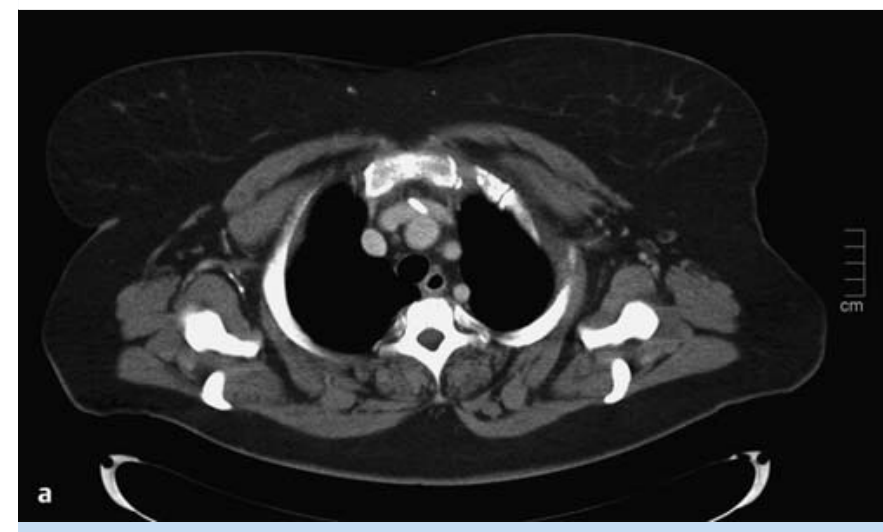

Fig. $3 \mathbf{a}$ and $\mathbf{b}$ Axial, contrast-enhanced computed tomography (CT) thoracic image (soft reconstruction kernel, soft-tissue window setting). New streaky/pitted densifications due to fat necrosis are visible in the left breast

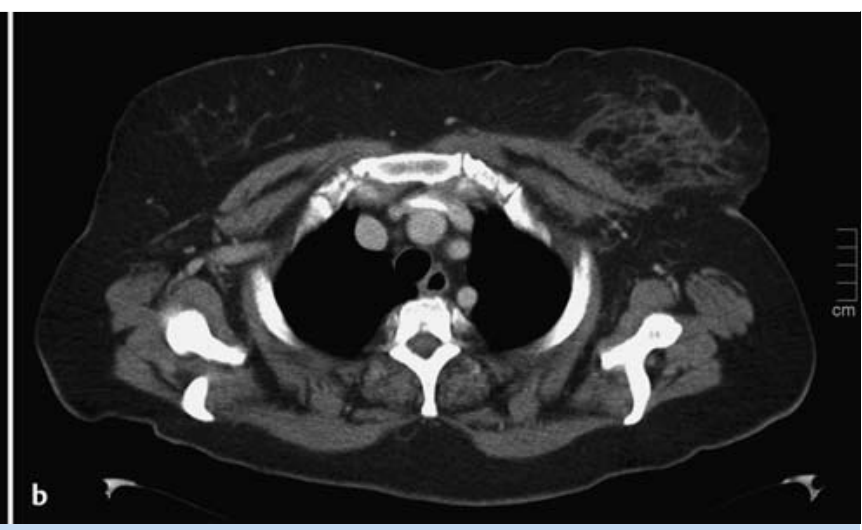

(b). a shows the unremarkable appearance of the same area prior to folinic acid extravasation.

magnetic resonance tomography (MRT) or biopsy with histological assessment.

\section{Steps}

$\nabla$

- Careful consideration of the patient's prior medical history is very important in breast diagnostics and may often be decisive for the correct diagnosis.

- A good knowledge of the mammographic and sonographic features of fat necrosis can reduce the number of unnecessary biopsies.

\section{Conflict of Interest}

$\nabla$

None. 


\section{References}

1 Telisselis P, Heers G, Plock B et al. Emergency open surgical treatment of extravasations of cytostatic agents in the upper extremity. Handchir Mikrochir Plast Chir 2010; 42: 247-250

2 Adami NP, de Gutiérrez MG, da Fonseca SM et al. Risk management of extravasation of cytostatic drugs at the adult chemotherapy outpatient clinic of a university hospital. J Clin Nurs 2005; 14: 876-882

3 André T, Boni C, Mounedji-Boudiaf L et al. Oxaliplatin, fluorouracil, and leucovorin as adjuvant treatment for colon cancer. N Engl J Med 2004; 350: 2343-2351

4 Prey S, Paul C. Effect of folic or folinic acid supplementation on methotrexate-associated safety and efficacy in inflammatory disease: a systematic review. Br J Dermatol 2009; 160: 622-628
5 Vicini F, Beitsch PD, Quiet CA et al. Three-year analysis of treatment efficacy, cosmesis, and toxicity by the American Society of Breast Surgeons MammoSite Breast Brachytherapy Registry Trial in patients treated with accelerated partial breast irradiation (APBI). Cancer 2008; 112: 758-766

6 Tan PH, Lai LM, Carrington EV et al. Fat necrosis of the breast - a review. Breast 2006; 15: 313-318

7 Hogge JP, Robinson RE, Magnant CM et al. The mammographic spectrum of fat necrosis of the breast. Radiographics 1995; 15: 1347-1356

8 Bilgen IG, Ustun EE, Memis A. Fat necrosis of the breast: clinical, mammographic and sonographic features. Eur J Radiol 2001; 39: 92-99

9 Soo MS, Kornguth PJ, Hertzberg BS. Fat necrosis in the breast: sonographic features. Radiology 1998; 206: 261-269

Deutschsprachige Zusatzinformationen online abrufbar unter: www.thieme-connect.de/ejournals/toc/gebfra. 